\title{
Analysis of School Boards of Management Competencies in the Management of Funds for Subsidized Secondary Education in Kiminini sub- County in Kenya
}

\author{
Johnson Bulowa, Sarah Likoko \\ Department of Educational Planning and Management, Kibabii University
}

\begin{abstract}
The study analysed the competencies for the Boards of Management in managing funds for subsidized secondary school education in Kiminini Sub-County in Kenya. The study adopted descriptive survey design. The target population included all the Boards of Management of 68 public secondary schools in Kiminini Sub-County. Purposive sampling technique was used to select 21 headteachers from 21 sampled schools. Data was analyzed using descriptive statistics. A questionnaire was used in data collection. The study established that current competencies of Boards of Management negatively and significantly influence effectiveness of managing funds in schools.
\end{abstract}

Keywords: Boards of Management, Competencies, Funds, Subsidized, Secondary Education

\section{INTRODUCTION}

$\mathrm{T}$ he competencies of Boards of Management in managing subsidized secondary school education funds is very important since funding is a key element in propagation of education. The management of finances by administrators is noted to be paramount due to the rising demand of education. This research dwells mainly on funding of schools which can be meaningful if the finances are well handled. Competency is a critical element that will ensure efficiency in handling finances.

Subsidized secondary school education is a new programme in Kenya that called for preparation, this calls for skills in effective finance handling and also knowledge coupled with the right attitude. Johnson (1994) carried out research on the management of British schools. He noted that there was a significant change in the role of head teachers and Boards of Management. He asserted that with the devolution of administrative power and financial control to schools the post of headship has become more critical to school success. He not only looked at head teachers but also brought on Boards of Management. The World Bank (2004) acknowledged vital relationship between education and economic development. These studies had, however, fallen short of seeking Boards of Management as key catalysts for educational development in developing countries. The studies also failed to look into the problems facing head teachers and Boards of Management in terms of skills they require in order to be effective and efficient in financial handling. Emerging developments like subsidized funds in day secondary schools by the government demands that principals who are chief accounting officers of the institutions needed additional training in finances. Flippo (1984) established that the development of any institution depended on the status of their training. The study points out the need for preparation before an individual is given additional responsibility. Preparedness to handle finances goes beyond training and demand for attitude change.

From the above studies, it can generally be asserted that training for principals and Boards of Management is valuable. Training on financial matters should be a pre-condition for the success of any secondary school. Training is therefore necessary and useful and has to be continuous. It can also be argued that formal training in school management be a prerequisite for the post of principal in a secondary school. Mutiva, (2004) found out that financial management, experience and availability of resources both human and financial were key areas of concern. Therefore, managers and administrators require management and administrative skills and knowledge. This is supported by Owiti (2010) in a study carried out in Kisumu County and Ndiangui (2011) carried out study in Laikipia County found out that majority of head teachers and Boards of Management were not trained in financial management skills. This is in line with the current study, however, conditions in Laikipia and Kisumu County are different from Trans-Nzoia County but it is an eye opener to the government since Boards of Management across the county are appointed to carry out the functions of ensuring that finances to the schools are channeled to the intended projects and therefore they require financial skills in preparation of managing subsidized day secondary school education. Hencewhat might be happening in Kiminini subcounty in terms of preparedness of Boards of Management to manage subsidized secondary school education is set to be studied. This was unraveled by the proposed study. 


\section{RESULTS AND DISCUSSION}

\subsection{Competencies of Boards of Management in Managing Funds in Subsidized Day Secondary Schools Education}

Key: SA-strongly agree-5, A-agree-4, N-Neutral-3, SD- strongly disagree-22, D-disagree-1

Table 1: Competencies of Boards of Management and Management of Funds

\begin{tabular}{|c|c|c|c|c|}
\hline Statement & $\mathrm{f}$ & $\%$ & Mean & Std \\
\hline $\begin{array}{c}\text { The Boards of Management } \\
\text { have skills in effective finance } \\
\text { managing }\end{array}$ & 24 & 53 & 1.02 & 0.912 \\
\hline $\begin{array}{l}\text { The Boards of Management } \\
\text { have knowledge in effective } \\
\text { finance managing }\end{array}$ & 23 & 52 & 1.22 & 0.921 \\
\hline $\begin{array}{l}\text { The Boards of Management } \\
\text { have the right attitude for } \\
\text { effective financial management }\end{array}$ & 25 & 56 & 4.03 & 1.984 \\
\hline $\begin{array}{l}\text { There is change in the role of } \\
\text { head teachers and Boards of } \\
\text { Management on financial } \\
\text { management. }\end{array}$ & 25 & 56 & 4.00 & 2.134 \\
\hline $\begin{array}{l}\text { Boards of Management is key } \\
\text { catalysts for educational } \\
\text { development }\end{array}$ & 28 & 63 & 4.64 & 2.341 \\
\hline $\begin{array}{l}\text { Experience of Boards of } \\
\text { Management is a key areas of } \\
\text { concern in management of } \\
\text { funds. }\end{array}$ & 28 & 63 & 4.64 & 0.967 \\
\hline $\begin{array}{l}\text { There is lack of preparedness of } \\
\text { Boards of Management to } \\
\text { manage Subsidized Secondary } \\
\text { School Education. }\end{array}$ & 30 & 67 & 4.67 & 1.029 \\
\hline $\begin{array}{l}\text { Low level of education of } \\
\text { Boards of Management } \\
\text { members affects the } \\
\text { management of funds in schools }\end{array}$ & 27 & 61 & 4.53 & 2.038 \\
\hline & & & & \\
\hline
\end{tabular}

The Table 1 , above shows that $24(53 \%)$ of the respondent disagree that (mean 1.02) the Boards of Management have necessary skills for effective finance managing. The small standard deviation (0.912) implies that there is no significant difference between the sample mean and the population mean.

The results show that $23(52 \%)$ of the respondent disagree that (mean 1.22) the Boards of Management have necessary knowledge for effective finance managing. The small standard deviation (0.921) implies that there is no significant difference between the sample mean and the population mean.

The results show that $25(56 \%)$ of the respondent agree that (mean 4.03) the Boards of Management have the right attitude for effective financial management. The small standard deviation (1.984) implies that there is no significant difference between the sample mean and the population mean.

The results show that $25(56 \%)$ of the respondent agree that (mean 4.00) there is change in the role of head teachers and Boards of Management on financial management. The small standard deviation (2.134) implies that there is no significant difference between the sample mean and the population mean.
The results show that $28(63 \%)$ of the respondent agree that (mean 4.64) Boards of Management is key catalysts for educational development. The small standard deviation (2.341) implies that there is no significant difference between the sample mean and the population mean.

The results show that 28(63\%) of the respondent strongly agree that (mean 4.64) experience of Boards of Management is a key areas of concern in management of funds. The small standard deviation (0.967) implies that there is no significant difference between the sample mean and the population mean.

The results show that $30(67 \%)$ of the respondent strongly agree that (mean 4.67) there is lack of preparedness of Boards of Managementto manage Subsidized Secondary School Education. The small standard deviation (1.029) implies that there is no significant difference between the sample mean and the population mean.

The results show that $27(61 \%)$ of the respondent strongly agree that (mean 4.53) low level of education of Boards of Managementaffects the management of funds in schools. The small standard deviation (2.038) implies that there is no significant difference between the sample mean and the population mean. Most school headteachers were certain that most of the Boards of Management had no financial management skills and relied on their report.

Table 2:Chi-Square Tests for Competence of Boards of Managementand Management of FundsChi-Square Tests

\begin{tabular}{|c|c|c|c|}
\hline & Value & df & $\begin{array}{c}\text { Asymp.Sig. } \\
(2 \text {-sided) }\end{array}$ \\
\hline Pearson Chi-Square & $41.521 \mathrm{a}$ & 27 & .000 \\
\hline Likelihood Ratio & 43.818 & 27 & .000 \\
\hline $\begin{array}{c}\text { Linear-by-Linear } \\
\text { Association }\end{array}$ & 41.384 & 1 & .000 \\
\hline N of Valid Cases & 45 & & \\
\hline
\end{tabular}

a. 23 cells $(57.5 \%)$ have expected count less than 5 . The minimum expected count is 22 .

In table 2 above, the significance value is so low that it is displayed as .000 , which means that it would appear that competence of the Boards of Management and effective funds management are indeed related.

Table 3: Correlation between Competencies of Members and Management of Funds

\begin{tabular}{|c|c|c|}
\hline \multicolumn{2}{|c|}{} & Effectiveness of managing funds \\
\hline \multirow{3}{*}{\begin{tabular}{c} 
Competenci $\begin{array}{c}\text { es of } \\
\text { Members }\end{array}$ \\
\cline { 2 - 3 }
\end{tabular}} & $\begin{array}{c}\text { Pearson } \\
\text { Correlation }\end{array}$ & $\begin{array}{c}\text { Sig. (2- } \\
\text { tailed) }\end{array}$ \\
\cline { 2 - 3 } & $\mathrm{N}$ & $-.571^{* *}$ \\
\hline \multicolumn{2}{|c|}{$* *$ Correlation is significant at the 0.01 level (2-tailed). } \\
\hline
\end{tabular}

Table 3 above show that Competencies of Boards of Management negatively and significantly influence effectiveness of managing funds at $\mathrm{r}=.571^{* *}, \quad \mathrm{P}<.05$. 
Calculating the coefficient of determinant R, Competencies of Boards of Management contributes $32.60 \%$ variability to effectiveness of managing funds when other factors are held constant.

The analysis results established that the respondent disagree that the Boards of Management have necessary skills for effective finance managing and that the Boards of Management have necessary knowledge for effective finance managing.

The analysis results also established that the respondent agree that the; Boards of Management have the right attitude for effective financial management, there is change in the role of head teachers and Boards of Management on financial management, Boards of Management is key catalysts for educational development, experience of Boards of Management is a key areas of concern in management of funds, there is lack of preparedness of Boards of Management to manage funds for Subsidized Secondary School Education and low level of education of Boards of Management affects the management of funds in schools.

In summary competencies of Boards of Management affects effective management of Subsidized Secondary School Education.

Further chi squire analysis revealed that competence of the Boards of Management and effective funds management are, indeed, related.

The correlation analysis established that Competencies of Boards of Management negatively and significantly influence effectiveness of managing funds contributing $32.60 \%$ variability to effectiveness of managing funds when other factors are held constant.

These findings are in agreement with many scholars. Johnson (1994) carried out research on the management of British schools. He noted that there was a significant change in the role of head teachers and Boards of Management. He asserted that with the devolution of administrative power and financial control to schools the post of headship has become more critical to school success. However, he focused mainly on headteachers roles but aspect of Boards of Management was not clearly illustrated.

Flippo (1984) established that the development of any institution depended on the status of their training. The study points out the need for preparation before an individual is given additional responsibility. Preparedness to manage finances goes beyond training and demand for attitude change. Therefore, training for principals and Boards of Management is valuable. Training on financial matters should be a precondition for the success of any secondary school.

The findings of this study are supported by Owiti (2010) in a study carried out in Kisumu County and Ndiangui (2011) carried out study in Laikipia County found out that majority of head teachers and Boards of Management were not trained in financial management skills.

Similarly, Momanyi\&Chumba (2013) revealed that reasons for non-completion of projects on time includes low level of education of Boards of Management, the type of school, length of stay of the principal and support from the sponsor.

\section{CONCLUSION}

Based on the findings, the study concludes that competencies of Boards of Management negatively and significantly influence effectiveness of management school finances.

\section{REFERENCES}

[1] Momanyi, J \&Chumba, S.(2013). Determination of educational projectscompletion time in secondary schools in Kenya; International journal advanced research (2013) Vol.1 issue 3,194200

[2] Owiti, B.H. (2010) ."Challenges facing management of free primaryeducation in Kenya; A case study of Kedibo division, Kisumu West District, Kenya: Unpublished thesis.

[3] Mutiva.(2004).Assessment of Human and Financial Resources to the Success of an Institution: A Case study of Tongaren division, BungomaNorth District, Kenya.

[4] Ndiangui.(2011). Influence of the Level of Training of Head Teachers andBoards of Management in Financial Management, Segera ward, Laikipia North Sub-County, Laikipia County. 